\title{
Radiographic and histological evaluation of bisphosphonate alendronate and metotrexate effects on rat mandibles inoculated with Walker 256 carcinosarcoma $^{1}$
}

\author{
Avaliação radiográfica e histológica do efeito do bisfosfonato alendronato e do \\ metotrexato na mandíbula de ratos inoculados com carcinossarcoma 256 de Walker ${ }^{1}$
}

\author{
Ana Paula Negreiros Nunes Alves², Cláudia do Ó Pessoa ${ }^{3}$, Letícia Costa-Lotufo ${ }^{3}$, Manoel Odorico Moraes Filho ${ }^{3}$ \\ 1. Research performed at Experimental Oncology Laboratory, Department of Pharmacology and Physiology, Federal University of Ceará (UFC), Brazil. \\ 2. PhD, Associate Professor, Department of Oral Pathology, UFC, Brazil. \\ 3. PhD, Associate Professor, Department of Pharmacology and Physiology, UFC, Brazil.
}

\begin{abstract}
Purpose: To investigate the effects of bisphosphosnate alendronate (ALD) and metotrexate (MTX) on an experimental model of Walker 256 carcinosarcoma developed in the oral cavity of rats. Methods: Walker 256 carcinosarcoma cell suspension $(0,1 \mathrm{~mL})$ containing $10^{6} \mathrm{cell} / \mathrm{mL}$ was implanted in the alveoli of the first and second molars. The animals were divided and treated with saline, MTX, ALD, and MTX plus ALD. Later, the animals were sacrificed, the tumors were measured and the mandibles were removed for radiographic and histological analysis. Results: In the control group, the radiographic images demonstrated radioluscency with poorly defined borders, and the microscopic examination revealed tumor infiltration into the peripheral and central regions of the bone. Areas of necrosis were commonly seen. In the treated groups with ALD, associated or not with MTX, the radiographic analysis revealed circumscribed tumorinduced osteolysis and various degrees of radiotransparence; while, histologically, preserved bone trabeculae with osteoid formation was observed among malignant cells. Conclusion: The bisphosphonate alendronate exherted an osteoprotective effect and induced bone neoformation on the Walker 256 carcinosarcoma inoculated in rat mandibles. The combination of metotrexate with bisphosphonate alendronate is more successful than treatment with the agents alone in controlling the growth of neoplastic cells and in stimulating reactive new bone. Therefore, this may be an alternative treatment to malignant lesions of maxillaries with osteolysis.
\end{abstract}

Key words: Mouth Neoplasms. Animal Experimentation. Carcinoma 256, Walker. Alendronate. Rats.

\section{RESUMO}

Objetivo: Avaliar o efeito do bisfosfonato alendronato (ALD) e do metotrexato (MTX) em modelo do carcinossarcoma 256 de Walker na mandíbula de ratos. Métodos: Uma suspensão de células tumorais do carcinossarcoma 256 de Walker $(0,1 \mathrm{~mL})$, na concentração de $10^{6}$ células $/ \mathrm{mL}$, foi implantada nos alvéolos de ratos previamente abertos por exodontia. Os animais foram divididos em grupos e tratados com salina, MTX, ALD e associação do MTX com ALD. Após o sacrifício, os tumores foram medidos e as mandíbulas removidas para exames radiográfico e histológico. Resultados: No exame radiográfico do grupo controle foi verificada área lítica, sem evidência de reparo na região dos alvéolos, e no microscópico, infiltração óssea periférica e central, de pequenas células tumorais com diversas áreas de necrose. Nos grupos tratados com ALD, associado ou não ao MTX, a análise radiográfica mostrou redução da osteólise tumor-induzida com graus variados de radiotransparência na estrutura óssea; enquanto que, na análise histopatológica, trechos de tecido ósseo preservado, com formação de osteóide em meio a células tumorais foram observados. Conclusão: O bisfosfonato alendronato exerceu um efeito osteoprotetor e induziu neoformação óssea em mandíbulas de ratos implantadas com células de carcinossarcoma de Walker 256. A combinação do metotrexato com o bisfosfonato alendronato foi mais eficaz que o tratamento com os agentes isoladamente no controle do crescimento das células neoplásicas e na estimulação da formação óssea. Sendo assim, essa associação constitui-se uma alternativa de tratamento das neoplasias malignas dos maxilares com invasão e comprometimento ósseo.

Descritores: Neoplasias Bucais. Experimentação Animal. Carcinoma 256 de Walker. Alendronato. Ratos. 


\section{Introduction}

Worldwide, head and neck cancers account for $10 \%$ of malignant tumors, while $40 \%$ of those are situated in the oral cavity. In some countries of Asia, this appears as the most common type of cancer and may be associated to cultural habits and chewing "betala" (popular Indian plant) and tobacco ${ }^{1}$. In Brazil, oral cavity cancers are in the $7^{\text {th }}$ position among the most common cancer sites ${ }^{2}$. Malignant neoplasms of maxillaries and mandibles, rather primary or metastatic, are considered to be rare when compared to soft tissue tumors. However, pathological resorptions of bone alveoli seen in a variety of malignant neoplasms are severe and serious, leading to premature microfractures, hypocalcaemia and intense pain ${ }^{3}$. The osteoclasts play an important role in the pathogenesis of this complication ${ }^{3,4,5}$. The activation and maintenance of the bone resorption are intimately related to an immune and humoral response, as well as to an inflammatory reaction, with the production of cytokines and prostaglandins ${ }^{3,4,5}$. When blood vessels are invaded by tumor cells, local ischemia is initiated which may lead to a coagulative necrosis contributing to tumor-induced osteolysis ${ }^{6}$. The treatment of mouth cancers is particularly mutilating, many times drawing the patient away from family, social and professional reintegration, rather partially of definitively ${ }^{7}$. Treatments must offer a better opportunity of cure, the preservation of the organ and life quality. In the effort of finding new therapy alternatives, many techniques are being established. Therapeutic methods applicable to mouth cancers are surgery, radiotherapy and, in selected cases, chemotherapy can be used, associated or isolated. Primarily, chemotherapy can be applied in advanced cases, aiming at reducing the tumor size, to be followed, then, by radiotherapy or surgery ${ }^{8}$. The involvement of maxillary bones in primary lesions or metastatic sites of solid tumors in cancer patients are a great problem for oncologists, radiotherapists, orthopaedic surgeons and maxillofacial surgeons ${ }^{4}$. Bone metastases are essentially osteolytic, increasing bone resorption pathological fractures ${ }^{5}$. As mentioned before, osteoclasts develop a crucial role in the cancer-induced bone destruction. For this reason, and for many years, there has been an increased interest in compounds that inhibit osteoclastic activity; among those, there are the bisphosphonates ${ }^{3,4,5}$. The bisphosphonates are non-hydrolable analogues of inorganic pyrophosphate, a naturally occurring polyphosphate found in sera and urine, which can prevent calcification of mineral bone by binding with new hydroxiapatite crystals ${ }^{9}$. Bisphosphonates can prevent bone resorption by inducing the production and maturation of osteoclasts. In organ cultures, these agents affect the genesis of mature osteoclasts possibly by interfering in the recognition of some matrix factors which are necessary for transformation, maturation or fusion of osteoclast precursors. The bisphosphonates can prevent bone resorption by stimulation of secretion of osteoclasts inhibitors or by inducing osteoclast apoptosis?.
The alendronate, a potent third generation bisphosphonate, accumulates in resorption areas, over clasts, which adhere normally to the bone surface but do not present a wrinkled edge, indicative of active resorption. There are no evidences that alendronate is metabolized by animals or human beings, therefore it does not produce cytotoxic metabolites ${ }^{9,10}$. This study aims on evaluating, through radiographic and histopathological analyses, the effects of bisphosfonate, associated or not with metotrexate, on rat mandibles inoculated with Walker 256 carcinosarcoma, a model previously established ${ }^{11}$.

\section{Methods}

\section{Animals and tumor cells}

Female Wistar rats, weighing between 140 and $250 \mathrm{~g}$, provided by the Central Animal House at the Federal University of Ceará, were divided in groups of 10 and maintained at the Biotery of the Department of Physiology and Pharmacology at $24^{\circ} \mathrm{C}$ with a $12 \mathrm{~h}$ light-dark cycle and food and water ad libidum. Tumor cells were used for Walker 256 carcinosarcoma were maintained in laboratory by sequential intramuscular inoculations in the right groin of Wistar rats. All experiments were executed in accordance with the precepts of research ethics with laboratory animals, having been submitted and approved by the committee of ethics in research with laboratory animals from the Federal University of Ceará.

\section{Tumor implant procedure}

Animals $(n=50)$ were anesthetized by intraperitoneal injection of $10 \%$ chloral hydrate to be submitted to the exodontia procedure of first and second inferior right molars. With the open alveoli cavities, $0.1 \mathrm{~mL}$ of a tumor cell suspension at $10^{6}$ cells $/ \mathrm{mL}$ was inoculated in the groups to be treated with saline (negative control), alendronate (ALD), metotrexate (MTX) and the association of alendronate and metotrexate (ALD + MTX). Next, the animals were put back in cages and remained under observation until the termination of the anesthetics effect, when they returned to the Biotery.

\section{Treatment protocol}

Negative control group animals were treated with saline on the 7th, 14th, 21st and 28th day after surgery. Each animal received a mean volume of $0.3 \mathrm{~mL}$ of physiological solution. Animals were sacrificed on the $35^{\text {th }}$ day and their mandibles were extracted. Positive control group animals received saline treatment $(0.3 \mathrm{~mL})$ on the $7^{\text {th }}$ and $14^{\text {th }}$ day. Death was acknowledged from the 12th day on, being finalized on the $18^{\text {th }}$. Following each animal death, the mandibles were extracted. The 3 rd experimental group was designated for the alendronate therapy. The treatment was 
conducted orally, using the gavage proceeding and a $3 \mathrm{mg} /$ $\mathrm{kg}$ of animal body weight. The animals received a single dose of alendronate on the $7^{\text {th }}$ day after tumor inoculation, for, by the $14^{\text {th }}$ day, none of the animals remained alive. All mandibles were removed after death. For the MTX treated group, animals received intra-peritoneal injections of MTX $\left(25 \mathrm{mg} / \mathrm{m}^{2}\right)$ on the $7^{\text {th }}, 14 \mathrm{th}, 21 \mathrm{st}$ and 28 th day after tumor inoculation. Animals treated with the association of MTX and alendronate received MTX intra-peritoneally on the $7^{\text {th }}, 14$ th, $21 \mathrm{st}$ and $28^{\text {th }}$ day and alendronate $(3 \mathrm{mg} / \mathrm{kg})$ orally on the $5^{\text {th }}, 12^{\text {th }}, 19^{\text {th }}$ and $26^{\text {th }}$ day. Drugs were administrated on alternate days due to known toxic effects of the chemotherapeutic drugs and the unknown pharmacological effects of double administration of MTX and alendronate. Alendronate administration volume varied between 1,30 a $2,25 \mathrm{~mL}$, depending on the animal weight. Only one animal received two doses on the treatment scheme; the others received three. After death, the mandibles were removed. All mandibles were fixed in formaldehyde $10 \%$ for $24 \mathrm{~h}$ and radiographed using a Odontology Radiography System.

\section{Radiographic analyses}

All mandibles from the 5 experimental groups were radiographed in X-ray for periapical takes (Planmeca Prostyle Intra). Exposure time was fixed for each group due to variations in tumor sizes, having been established as listed below:

\begin{tabular}{c|c}
\hline Experimental group & Exposure time \\
\hline Negative control & $0,18 \mathrm{~s}$ \\
\hline Positive control & $0,24 \mathrm{~s}$ \\
\hline Alendronate treatment & $0,28 \mathrm{~s}$ \\
\hline Metotrexate treatment & $0,24 \mathrm{~s}$ \\
\hline Metotrexate + Alendronate treatment & $0,20 \mathrm{~s}$ \\
\hline
\end{tabular}

Periapical radiographic film was used (Dental Intraoral E-Speed Film Kodak) and development of all shots was held in an automatic processor (A/T 2000M Airtechniques, inc) during a mean time of 5 minutes. For radiographic analyses, the shots were digitalized to permit more faithful analyses.

\section{Histopathological analyses}

Following the radiographic shots, the tumor was dissected from the mandibles, thus separating the soft part of the neoplasm. The mandibles were decalcified with $10 \%$ nitric acid for $24 \mathrm{~h}$, and cut in to small pieces. Tumor and mandible samples were sent for histopathological analyses. Slides of extra and intra-bone tumor tissue were prepared using routine staining with hematoxilin and eosin and submitted to histopathological analysis under light microscope. Tumor evaluation was based on the following criteria: induced central and peripheral tumor infiltration, tumor- and antineoplastic-induced tissue necrosis, presence of osteoclasts and involvement of adjacent dental tissue. For measuring necrosis in bone tissues induced by the antitumoral activity of the chemotherapeutic drug, and adaptation Huvos Index ${ }^{12}$ was done, and the post-chemotherapy evaluation index was established (Table 1), on which, like the previous, the tissues were rated in degrees I, II, III and IV.

TABLE 1 - Post-chemotherapy evaluation index

\begin{tabular}{l|l}
\hline Grade I & Little or no necrosis \\
\hline Grade II & $\begin{array}{l}\text { Necrotic areas among histologically } \\
\text { viable tumor areas }\end{array}$ \\
\hline Grade III & $\begin{array}{l}\text { Predominant necrosis with scattered sites } \\
\text { of viable tumor }\end{array}$ \\
\hline Grade IV & $\begin{array}{l}\text { No histological evidence of viable tumor } \\
\text { areas }\end{array}$ \\
\hline
\end{tabular}

\section{Results}

Radiographic and histological analyses

$\underline{\text { Negative control group }}$

Radiographic findings show anatomical repair constituted by depression of the posterior region of the $3^{\text {rd }}$ inferior molar at the entrance of the mandible canal, represented by the radiolucent area circumscribed in the radiopaque halo. The area of the exodontias of the $1^{\text {st }}$ and $2^{\text {nd }}$ inferior molars presented homogeneously radiopaque and, in some cases, showed a trabeculae aspect of the bone alveoli, indicating bone repair (data not showed). The microscopic analysis showed histological sections constituted by haversian mature bone tissue, exhibiting normal bone trabeculae and osteocytes distributed along the mineralized intracellular substance (Figure 1A). In the marrow spaces, red bone marrow, megakaryocytes and fibrosis sections were observed. The tooth (molar) was represented by well defined layers of dentin, pulp and cement, with no histological alterations. Dentinary tubules were evident and the dental pulp was presented as less dense form of connective tissue, high vascularity and with a layer of odontoblasts in the odontogenesis area. Those cells were columnaries or cubicals with side ramifications (Figure 1B). 

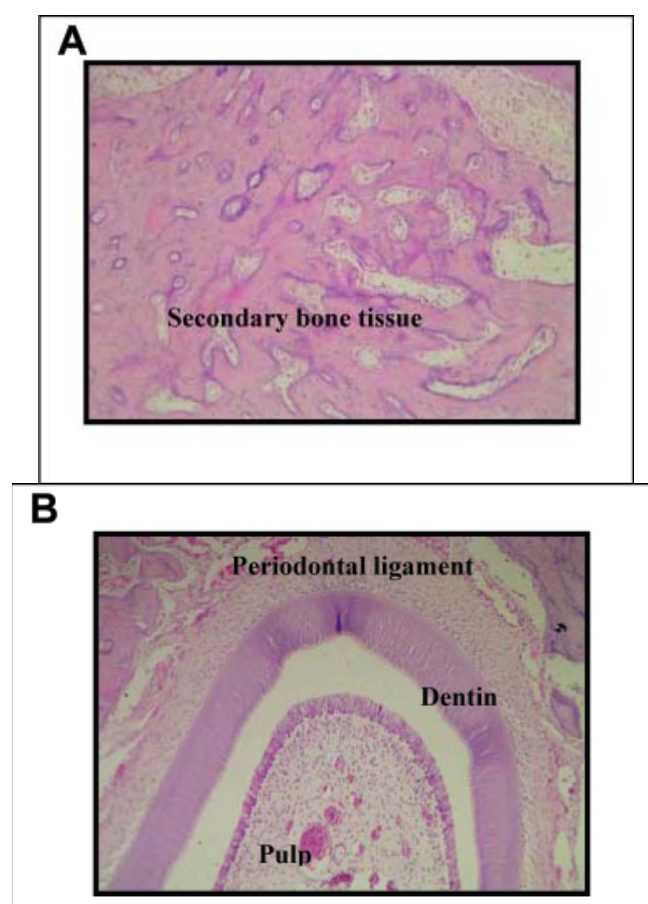

FIGURE 1 - A) Photomicrograph of a section of bone tissue of a mandible with harversian system, without tumor. HE 100X. B) Molar tooth showing dentin, pulp and periodontal ligament. HE 100X.

\section{Positive control group}

On the posterior region of the inferior $3^{\text {rd }}$ molar, anatomic radiolucent repair could be seen circumscribed by a radiopaque halo. There were no radiographic signs of root resorption. An irregular tumor mass could be observed on the soft tissue and, on the teeth extraction regions where the tumor was implanted, there was imprecise bone pattern with invasion of the mandibular canal, showing variations in radiotransparency which can remind the classic radiographic aspect of osteossarcomas described as "spiking" resorption (data not showed). The microscope examination of the tumor soft parts detected a mesenchymal neoplasia characterized by anisokaryosis, being the cells small, round, with irregular contour, loose chromatin and evident nucleoli. The cells were loosely organized with an alveolar arrangement tendency and large areas of coagulative necrosis (Figure 2A). The microscopic analyses of bone tissue verified the presence of cells with the same morphological pattern as described above, the ones that infiltrated the bone centrally and peripherally. The tumor cells were often found in nests and the bone surfaces with irregular borders. Fields of vascular invasions by neoplastic cells and death of osteocytes were also identified. Areas of coagulative necrosis were present and some osteoclasts were visualized (Figure 2B). The molar tooth at the tumor region did not present any histological alterations.
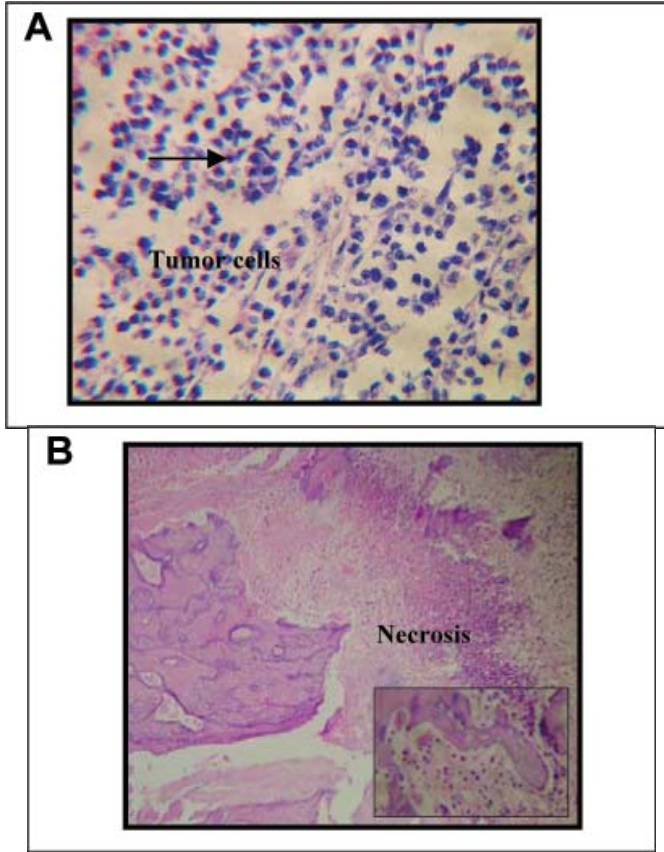

FIGURE 2 - A) Photomicrograph of malignant mesenchymal cells (Walker 256 Carcinosarcoma) in soft tissue in the positive control group. HE 100X. B) Nonvital bone exhibits loss of osteocytes from the lacunae and extensive necrosis. (HE 100X) and, in the detail, osteoclastics cells in higher magnification HE 400X.

\section{Alendronate treated group}

The tumor mass in the soft tissue is irregular and the lytic destruction of the alveolar bone at the areas of exodontias and implantation of tumor cells is less diffuse. The radiolucent area localized at the $3^{\text {rd }}$ molar region is present and there is no root resorption (data not showed). Microscopic analyses of the tumor soft parts detected a similar morphological pattern as the cells from the positive control, arranged in an alveolar disposition, sometimes distributed in a loose manner. The cells showed nuclear and cellular pleomorphism, a low mitotic index and vascular invasion. The coagulative necrotic areas were present on the same proportions as those found for the positive control group and, on a single case in which the tumor presented smaller dimensions $(9,7 \times 8,9 \mathrm{~mm})$, no necrosis was visualized. Central and peripheral tumor cell infiltration was observed in the mandibles. The cells were organized in blanquettes, singled or loose and, rarely, in nests. Regardless of the presence of neoplastic cells, bone trabeculae were well preserved in many fields. Irregular bone surfaces associated to loss of osteocytes and coagulative necrosis were also visualized. Vascular invasion was detected in all of the analyzed cases and osteoid tissue was found in three cases. Osteoclasts were verified in one of the cases. Evaluation of post-chemotherapy index revealed that all cases were classified as grade I (Table 2). Molar tooth did not show any histological alterations (Figures $3 \mathrm{~A}$ and $3 \mathrm{~B}$ ). 


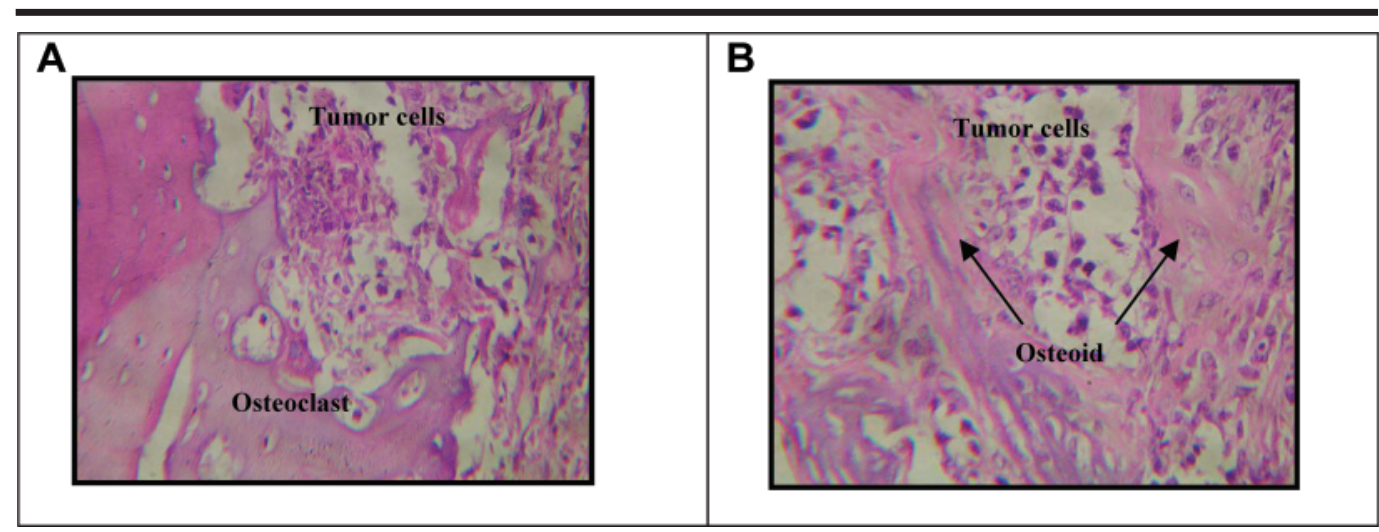

FIGURE 3 - A) Photomicrograph of Walker 256 Carcinosarcoma from the alendronate treated group displaying malignant mesenchymal cells and bone trabeculae with osteocytes and osteoclasts. HE 400X. B) Trabeculae of osteoid tissue alongside with undifferentiated malignant cells. HE 400X.

TABLE 2 - Results from the evaluation of the postchemotherapy index with alendronate, metotrexate and the association of metotrexate and alendronate

\begin{tabular}{lccc}
\hline Graduation & Alendronate & Metotrexate & $\begin{array}{c}\text { Association of } \\
\text { Metotrexate and } \\
\text { Alendronate }\end{array}$ \\
\hline Grade I & 10 & 1 & 0 \\
Grade II & 0 & 3 & 4 \\
Grade III & 0 & 3 & 6 \\
Grade IV & 0 & 2 & 0 \\
\hline
\end{tabular}

\section{Metotrexate treated group}

The analysis revealed presence of anatomical repair at the posterior region of the $3^{\text {rd }}$ molar. Reminiscent molar tooth did not show signs of root resorption. Tumor mass on soft tissue were smaller in size and the bone tissue corresponding to exodontias areas showed variations on radiopacity levels, with preservation of the mandibular canal image (data not showed). Neoplasia of the soft tissue showed the same morphological characteristics as those described for the positive control group, but showing more extensive coagulative necrosis areas and a lower number of mitosis. Bone tissue was invaded, both, centrally or peripherally, by tumor cells. Those organized themselves in blanquettes with no nest formation. Bone trabeculae were better preserved, when compared to positive control. Bone surfaces with irregular borders and osteocyte death were also seen (Figure 4A), along with bone reactive fields (Figure 4B). According to the post-chemotherapy evaluation index, two cases were classified as grade IV; three were grade III; three were grade II and only one was classified as grade I (Table 2). In four samples we found osteoclasts, sometimes isolated, others in islets. Basophilic material similar to calcification areas was identified in two samples. There were no histological alterations in the molar tooth. In two cases it was not observed, macroscopically, tumor growth on soft and bone tissue.

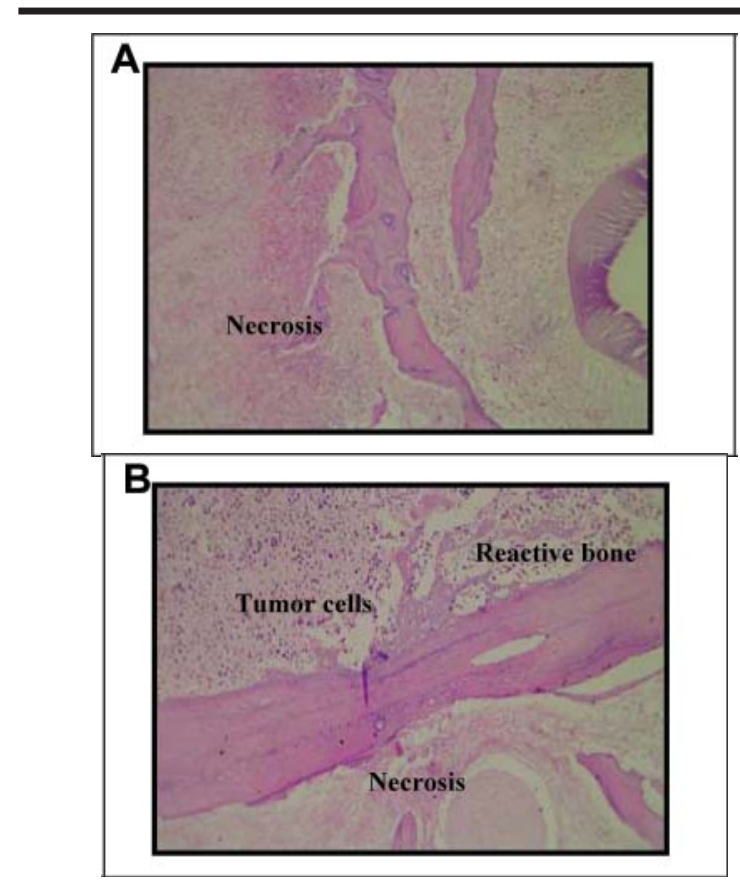

FIGURE 4 - A) Photomicrograph from MTX treated group presenting an irregular destruction of bone trabeculae and coagulative necrosis area. HE 100X. B) Osteoid production may be seen among tumor cells invading bone trabeculae. HE 100X

\section{Metotrexate + Alendronate treated group}

Size reduction of the tumor mass on soft tissue and exodontia areas was detected, alveolar ridge presented higher opacity, radiographic signs of bone neoformation, probably in different stages. Anatomical repair was present and there was no root resorption (data not showed). Histophatological analysis of soft parts from the neoplasia detected that tumor cells presented the same characteristics as those from the other studied groups. Pleomorphic cells, hyperchromatic, with vesicular nucleus, distributed loosely or in blocks or arranged in an alveolar manner 
were the predominant set of the neoplasia. Rare mitotic figures were seen and extensive coagulative necrosis was constant in all samples. On the mandible bone, central and peripheral tumor cell invasion was observed in all cases. At the adjacent areas to peripherical infiltration, there was reactive bone and, in one case, osteoclasts were present in that region. Centrally we verified extensive coagulative necrosis fields associated to irregular bone surfaces and death of osteocytes. In all cases, bone trabeculae were preserved and viable osteocytes were visualized, even among tumor cells and necrosis (Figure 5A). According to the post-chemotherapy evaluation index, six cases were classified as grade III and the other four were grade II (Table 2). On all samples analyzed we found osteoid tissue, sometimes on the periphery, others centrally or on both regions (Figure 5B). Clastic cells were seen in four cases (Figure 5B), vascular invasion was detected in nine cases and molar tooth did not show any histological alteration.
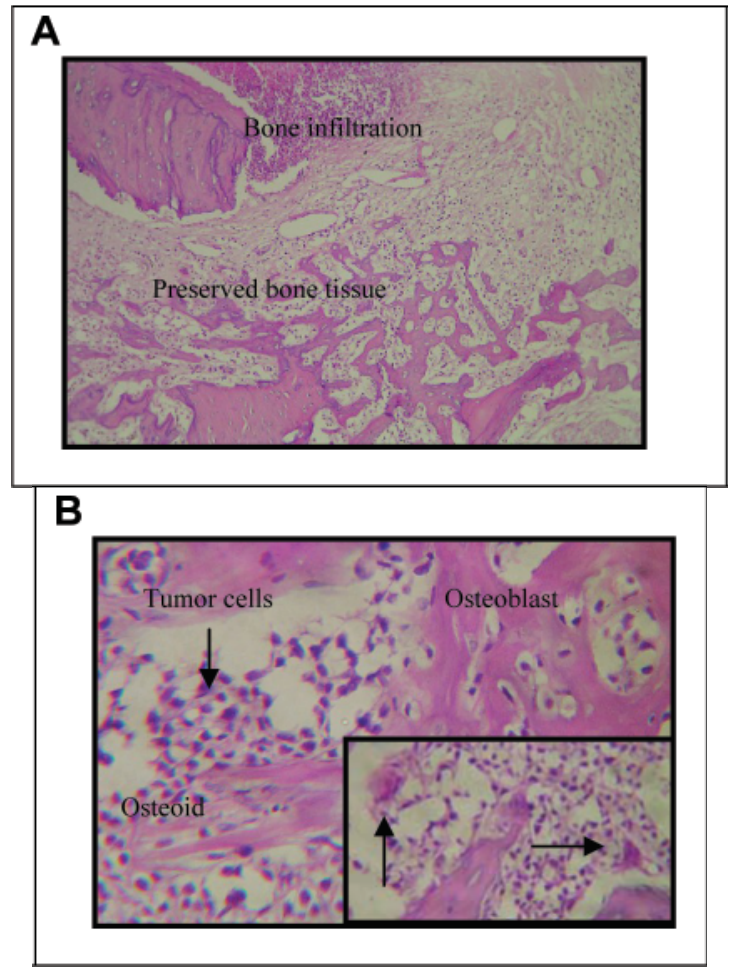

FIGURE 5 - A) Photomicrograph of Walker 256 Carcinosarcoma from animals treated with the association of MTX and alendronate showing preserved bone trabeculae and malignant cells. HE 100X. B) Osteoid trabeculae are surrouded by osteblasts and tumor cells (HE 400X), and in the detail, osteoclasts in the area of resorption trabeculae.(HE 400X)

\section{Discussion}

An important aspect related to oral and maxillofacial cancer is that primary tumors are frequently adjacent to bone structures. When there is absence of teeth, the subcortical progression of the tumor throughout teeth alveoli is faster. Besides that, it is associated to a straighten in the cortical mandible by the resorption of bone alveoli in a way that the neoplasm lesion can reach the mandible marrow easier. For the treatment of large tumors sectional -, composed excisions are required, which brings major damage, the main one being lip occlusion with oral incontinence. With the establishment of new experimental models of maligned neoplasias in bone tissue (mandible or maxilla) we can develop alternative treatments, thus reducing the cases of lytic destruction of mandible or maxilla bone, followed by functional or esthetics deformities from the aggressive treatments that the advanced illness demands ${ }^{7,8}$. The Walker 256 Carcinosarcoma inoculated in the mandible of the rat is capable of reproducing osteolytic forms of bone infiltration without the resorption of teeth roots ${ }^{11}$. There are few in vivo oral-facial bone invasion experimental models. However, literature describes experimental models of metastasis to the mandible bone by intracardiac injections of tumor cells $\mathrm{s}^{13,14}$. Differences on the bone microenvironment and the presence of teeth and other anatomical structures of the oral cavity can exert an important role, altering the development of bone metastasis. Moreover, tumor cells can suffer metastasis to adrenal glands and, more rarely, to other organs such as lungs, liver and brain, leading the animal to develop, rapidly, a case of cachexia and death $^{13}$. On the established model, the possibility of regional and distant metastasis is diminished, for the inoculation of the cell suspension is directly on the dentary alveoli, making it possible to observe the animal for a longer period of time. On all groups of the experimental model the presence of tumor-induced osteolysis was verified, which is characterized, according to available literature, by reduction of bone mass and destruction of bone structure, visualized on radiographic shots as delimited of diffused radiolucent lesions $\mathbf{s}^{3,15}$. Neoplastic cells of bone infiltrated solid tumors or at bone metastasis regions express known factors of bone resorption, as the granulocyte macrophage colony stimulating factor (GM-CSF), the parathyroid peptide related protein (PTHrP), prostaglandins (as specially PGE2), the transforming growth factor $\alpha(\mathrm{TGF} \alpha)$, insulin-like growth factors (IGF-1 e IGF-2) and catepsin D. Moreover, stromal cells secrete cytocins, such as IL-1, IL-6 e TNF $\alpha^{16}$ and express mRNA of essential factors for osteoclastogenesis, like the ligand RANK (osteoclastic differentiation factor). The later will connect to the RANK receptor, which activates NF- $\mathrm{BB}$ (nuclear transcription factor) located on hematopoietic precursors of osteoclasts, stimulating the formation of osteoclasts ${ }^{17}$. It is important to mention that the Wlaker 256 tumor cells, which were used in the present model, do not express mRNA for PTHrP, which stimulated bone resorption. However, high index of TNFa and other osteolytic cytocins are detected in the sera of tumor inoculated animals. These findings can be related to the immune response, but that induces a rapid bone loss ${ }^{9}$. Our results show a lytic radiographic image for the positive control group, associated to 
local osteolysis and subsequent loss of architectural integrity of bone tissue, when compared to the homogenous radiopaque image of the negative control group. The group that received treatment with metotrexate alone showed variations on the radiographic appearance of the bone pattern, with radiolucent and radiopaque sections, and theses findings are compatible with tissue repair. On the alendronate-treated group, there was a lytic area with no evidence of a possible alveoli bone repair, but in a less diffuse manner, suggesting an osteoprotective action ${ }^{15}$. On the associated treatment (alendronate + metotrexate), the radiographic image showed reduction of radiolucense and, on the areas of exodontias, the alveoli contours showed more radiopacity, a radiographic indicative of new bone formation, probably in an advanced stage. This way, bone response could be measured by the size reduction as well as by remineralization of lytic lesions ${ }^{15}$. We emphasize that, for the tumor inoculated experimental groups, root resorption associated to lesion progression was not verified. The cells responsible for bone, cementum and dentin resorption (osteoclasts, cementoclasts and dentinoclasts, respectively) have a very similar morphology, if not identical, and the tooth resorption process seams to be very similar to the bone resorption. Moreover, the combination of mineral components and hard tissue collagen seams to be essential for the initiation of the resorption process. Tooth resorption is characterized only be the participation of inflammatory events, with migration, differentiation and maintenance of the phagocytes mononuclear cells at the resorption site $^{19}$. Since the drugs used in this study exert immune-suppressive actions, these phagocytes may suffer alterations of function and number and, consequently, not be able to promote tooth resorption. Histopathological analyses of tumor inoculated mandibles confirmed the presence of anaplastic cells from the malignant neoplasia implanted. Central and peripheral bone infiltration, revealed cells with the same morphological pattern of those found on the supra and subadjacent mucosa, irregular bone surface and loss of osteocytes. For the positive control and alendronate treated groups, coagulative necrosis areas were seen on bone and soft tissues, in a similar way, suggesting death by hypoxia of tumor cells, probably as a consequence of vascular infiltration ${ }^{6}$. On the other hand, extensive necrotic areas was observed on the metotrexate and metotrexate associated with alentronate groups, resulting from the effects of the chemotherapy medication on bone and soft tissues. When compared with the positive control group, some of the reminiscent bone trabecula in the metotrexate treated group presented some fields of integrity, while in the metotrexate+alendronate treated group, preserved bone trabeculae with osteocytes were visualized even among tumor cells and necrotic areas. Mechanism of tumor-induced bone destruction associated to bone invasion or metastasis of mandible cancers is essential osteoclast-mediated ${ }^{3,4,14}$. In all tumor inoculated groups it was observed the presence of osteoclasts, isolated or in nests with a variable number. Osteoclasts inhibitors, such as the bisphosphonates, are capable of inhibiting or diminishing tumor induced bone resorption, having a great influence in life quality of treated patients, since it avoids pathological fractures ${ }^{14}$. Besides that, the bisphosphonates have high affinity for bone surface hidroxiapatite, being found, preferably, in bone formation or bone resorption sites ${ }^{9,18,20}$. The mechanisms by which bisphosphonates act on bone resorption on the cellular level involve the inhibition of formation and/or recruitment of osteoclast from immature precursor cells, inhibition of osteoclast activation, inhibition of osteoclastic activity and/or induction of apoptosis ${ }^{9,20}$. Recent evidences show that the osteoclasts produce factors, such as $\mathrm{PGE}_{2}$, IL-1 and TNF $\alpha$, that stimulate mature osteoclast activity. However, it is suggested that the mechanistic of the bisphosphonates is also by inhibiting the osteoblast production of osteoclast stimulators. Thus, direct inhibition of osteoclast activity is suggested, from in vivo observation, by the disappearing of the wavy borders, which is the convolute membrane of the osteoclasts associated with their activity. Bisphosphonates induce the disappearing of these borders, interrupting the bone lysis process ${ }^{20}$. For both alendronate-treated groups, we can see osteoclasts associated with the bone resorption areas, as well as to the osteoid formation. Finally, the aminobisphosphonates induce osteoclast apoptosis, inhibiting the enzymes from the mevalonate pathway and preventing prenilation, which is a translational modification (mainly geranylgeranylation) of small proteins that connect to GTP, which are essential for the vesicle traffic and maintenance of cytoskeleton integrity. It is important to emphasize that the mevalonate pathway is a biosynthetic pathway responsible for the production of cholesterol and isoprenoid lipids, such as geranylgeranylpyrophosphate (GGPP) and farnesilpyrophosphate (FPP). Geranylation is the linking of a 20 carbon lipid (geranylgeranyl) to certain proteins, including key regulatory G-proteins (GTPases) such as Ras, Rho and Rac. These constitute important signaling proteins which regulate a number of cellular processes of osteoclast functions. Geranylgeranylation is necessary to anchor these proteins to the cell membrane or to intracellular membranes. This way, the aminobisphosphonates inhibit the mevalonate pathway, no formation of FPP or GGPP occurs and, consequently, there is a loss of GTPases. The absence of this process results in a blockage or change of signalization events which finally leads to induction of caspases and apoptosis of osteoclasts ${ }^{9,20}$. Our results show that animals treated with alendronate bisphosphonate show a discrete reduction of tumorinduced osteolysis observed on the radiographic exam, where there were variations of the bone tissue appearance, as discussed previously. These finding were corroborated by the microscopic aspects, where we found sections of osteoid formation and reactive bone tissue, even among tumor cells and necrotic areas. This way, the alendronate was able to alter bone lysis induced by Walker 256 Carcinosarcoma.

\section{Conclusions}

The bisphosphonate alendronate exherted an osteoprotective effect and induced bone neoformation on the Walker 256 carcinosarcoma inoculated in rat mandibles. The combination of metotrexate with bisphosphonate alendronate is more successful than treatment with the agents alone in controling the growth of neoplastic cells and in stimulating reactive new bone. Therefore, this may be an alternative treatment to malignant lesions of maxillaries with osteolysis. 


\section{References}

1. Wünsch-Filho V. The epidemiology of oral and pharynx in Brazil. Oral Oncol. 2002;38:737-46.

2. Oliveira EF, Silva OMP, Blachman IT, Pio MRB. Perfil epidemiológico das neoplasias orais malignas no município de São Paulo, Brasil. Rev Odontol UNESP. 2005;34(4):141-7.

3. Kurth AA, Muller R. The effect of an osteolytic tumor on the three-dimensional trabecular bone morphology in an animal model. Skeletal Radiol. 2001;30(94):95-8.

4. Kurth AHA, Kim SZ, Sedlmeyer I, Hovy L, Bauss F. Treatment with ibandronate preserves bone in experimental tumour-induced bone loss. J Bone Joint Surg. 2000;82B:126-30.

5. Kurth AA, Kim SZ, Sedlmeyer I, Bauss F, Shea, M. Ibandronate treatment decreases the effects of tumorassociated lesions on bone density and strength in the rat. Bone. 2002;30(1):300-6.

6. Majno G, Joris I. Apoptosis, oncosis and necrosis: an overview of cell death. Am J Pathol. 1995; 146:3-15.

7. Dhooge IJ, Albers FW, van Cauwenberge PB. Clinical characteristics and diagnostic delay of head and neck cancer: results from a prospective study in Belgium. Eur J Surg Oncol. 1996;22(4):354-8.

8. Dimery IW, Hong WK. Overview of combined modality therapies for head and neck câncer. J Natl Cancer Inst. 1993;85:95-111.

9. Rogers MJ, Frith JC, Luckman SP, Coxon FP, Benford HL, Monkkonen J, Auriola S, Chilton KM, Russell RGG. Molecular mechanisms of action of bisphosphonates. Bone. 1999; 24(Suppl 5):S73-9.

10. Stepensky D, Golomb G, Hoffman A. Pharmacokinetic and pharmacodynamic evaluation of intermittent versus continuous alendronate administration in rats. $\mathrm{J}$ Pharmacol Sci. 2002;91(2):508-16.

11. Alves APNN, Guedes RC, Costa-Lotufo LV, Moraes MEA, Pessoa CO, Ferreira FVA, Moraes MO. Modelo experimental de tumor na cavidade oral de ratos com carcinosarcoma de Walker 256. Acta Cir Bras. 2004;19(4):406-14.
12. Picci P, Böhling T, Bacci G, Ferrari S, Sangiorgi L, Mercuri M, Ruggieri P, Manfrini M, Ferraro A, Casadei R, Benassi MS, Mancini AF, Rosito P, Cazzola A, Barbieri E, Tienghi A, Barch del Prever A, Comandone A, Bachini P, Bertoni F. Chemotherapy induced tumor necrosis as a prognostic factorin localized Ewing's sarcoma of the extremities. J Clin Oncol.1997;15:1553-9.

13. Sasaki A, Yoneda T, Terakado N, Alcalde RE, Suzuki A, Matsumura T. Experimental bone metastasis model of the oral and maxillofacial region. Anticancer Res. 1998;18(3A):1579-84.

14. Sasaki A, Nishiyama A, Alcalde RE, Lim DJ, Mese H, Nakayama S, Yokoyama S, Matsumura T. Effects of bisphosphonate on experimental jaw metastasis model in nude mice. Oral Oncol. 1999;35(5):523-9.

15. Morton AR, Howell A. Bisphosphonates and bone metastases. Br J Cancer. 1988;58(5):556-7.

16. Ishimi Y, Miyaura C, Jin CH, Akatsu T, Abe E, Nakamura Y, Yamaguchi A, Yoshiki S, Matsuda T, Hirano T. IL-6 is produced by osteoblasts and induces bone resorption. J Immunol. 1990;145(10):3297-303.

17. Papapoulos SE, Hamdy NA, van der Pluijm G. Bisfosfonatos en el tratamiento del carcinoma de próstata con metástasis oseas. Cancer 2000;88(12):3047-53.

18. Waki Y, Nomura M, Kasugai S, Ohya K, Miyamoto K. Walker 256/S Carcinosarcoma causes osteoporosislike changes through ectopical secretion of luteinizing hormone-releasing hormone. Cancer Res. 1999;59:1219-24.

19. Ne RF, Witherspoon DE, Gutmann JL. Tooth resorption. Quintessence Int. 1999;30:9-25.

20. Vasconcellos DV, Duarte MEL, Maia RC. Efeito antitumoral dos bisfosfonatos: uma perspectiva terapêutica. Rev Bras Cancerol. 2004;50(1):45-54.

\section{Acknowledgements}

We thank Silvana França dos Santos and Maria de Fátima Teixeira, for technical assistance and Paula C. Jimenez for revising the English language.

\section{Correspondence:}

Ana Paula Negreiros Nunes Alves

Av. Dep Oswaldo Studart, 362/401

60.411-260 Fortaleza-CE Brazil

ananune@terra.com.br
Conflict of interest: none Financial source: CNPq, FUNCAP, FINEP, BNB/FUNDECI.

Received: April 19, 2007

Review: June 20, 2007

Accepted: July 23, 2007

\section{How to cite this article}

Alves APNN, Pessoa CO, Costa-Lotufo L, Moraes Filho MO. Radiographic and histological evaluation of bisphosphonate alendronate and metotrexate effects on rat mandibles inoculated with Walker 256 carcinosarcoma. Acta Cir Bras. [serial on the Internet] 2007 Nov-Dec;22(6). Available from URL: http://www.scielo.br/acb 